\title{
EFFECT OF INCREASED DAILY INTAKE OF PROTEIN, COMBINED WITH A PROGRAM OF RESISTANCE EXERCISES, ON THE MUSCLE MASS AND PHYSICAL FUNCTION OF COMMUNITY-DWELLING ELDERLY WOMEN
}

\author{
H. Mori ${ }^{1}$, Y. Tokuda ${ }^{2}$
}

\begin{abstract}
Background: In elderly women, significant loss of muscle mass due to declining levels of estrogen secretion is a health concern. Increasing the recommended dietary allowance of protein intake has been included as a general health guideline to prevent age-related sarcopenia. Objectives: To investigate effects of light-to-moderate resistance training combined with increased protein intake on the muscle mass, strength, and physical function of community-dwelling elderly women. Design: The 12-week training program combined weight-bearing and resistance band exercises, performed 3 times per week. Setting: Hyogo Prefecture, in either City K or Town H. Practical Intervention: Women were randomly allocated to three groups: exercise with protein intake adjusted to the recommended daily allowance (RDA) of 1.0-1.1 g/ kg body weight/day (MP+EX group); exercise with protein intake adjusted above the RDA level at $1.2-1.3 \mathrm{~g} / \mathrm{kg}$ body weight/day (HP+EX group); and a control group receiving classroombased session on nutrition management, with protein intake adjusted to the RDA level (MP group). Measurements: Body weight and physical composition were measured by multi-frequency bioelectrical impedance analysis. Results: Exercise prevented decreases in muscle mass and strength and in performance of physical function tasks $(\mathrm{p}<0.05)$. Increasing dietary intake of protein above RDA level increased muscle mass $(\mathrm{p}<0.01)$, walking speed $(\mathrm{p}<0.01)$ and knee extensor strength $(\mathrm{p}<0.05)$. Conclusion: Adjusting protein intake to $1.2-1.3 \mathrm{~g} / \mathrm{kg}$ body weight/day, in combination with light-to-moderate resistance training, can improve body composition and physical function in elderly women. The result of this study could be effective in lowering the incidence of age-related sarcopenia.
\end{abstract}

Key words: Community-dwelling elderly, exercise, muscle mass, protein intake, sarcopenia.

\section{Introduction}

Aging is associated with a decrease in skeletal muscle mass and strength which leads to limitations in physical activities, increased risk for falls and overall lowering of the quality of life of elderly people (1-7). A specific health concern is the significant loss of muscle mass in elderly women due to declining levels of estrogen secretion (8). The resulting loss of strength is one of the primary factors of the higher incidence of falls in older women, compared to older men. Increasing the recommended dietary allowance of protein intake has been included as a general health guideline to prevent age-related sarcopenia (9-11).

1. Diabetes Therapeutics and Research Center, University of Tokushima, Tokushima, Tokushima, Japan; 2. Faculty of Health Science Department, Hyogo University, Hiraoka, Kakogawa, Hyogo, Japan

Corresponding Author: Dr. Hiroyasu Mori, Diabetes Therapeutics and Research Center, University of Tokushima, 3-18-15 Kuramoto, Tokushima, Tokushima 7708503, Japan, Phone number: +81 886337587, Fax Number: +81 886337589, Email: hiroyam31@gmail.com
The Japanese recommendations for dietary reference intakes (DRIs) indicate a daily protein intake of 1.0-1.1 $\mathrm{g} / \mathrm{kg}$ body weight/day for people aged $>65$ years (12). These DRIs do not include protein intake levels necessary for elderly individuals performing resistance exercises for the purpose of increasing skeletal muscle mass and physical function, knowledge required to optimize outcomes of exercise (13).

According to the Long-Term Care Prevention Service, which aims to increase musculoskeletal system function in the elderly, few elderly individuals practice highintensity resistance exercises using large-scale training equipment. Moderate-intensity resistance exercises performed using body weight and resistance bands provide an easy way for elderly people to exercise for the purposes of increasing skeletal muscle mass and physical function to prevent sarcopenia. Accordingly, the aim of our study was to evaluate the effectiveness of adjusting total protein intake to levels of $1.2-1.3 \mathrm{~g} / \mathrm{kg}$ body weight/day, a level exceeding the DRIs, on skeletal muscle mass and physical function in elderly women 
Figure 1

Flow chart of study participation

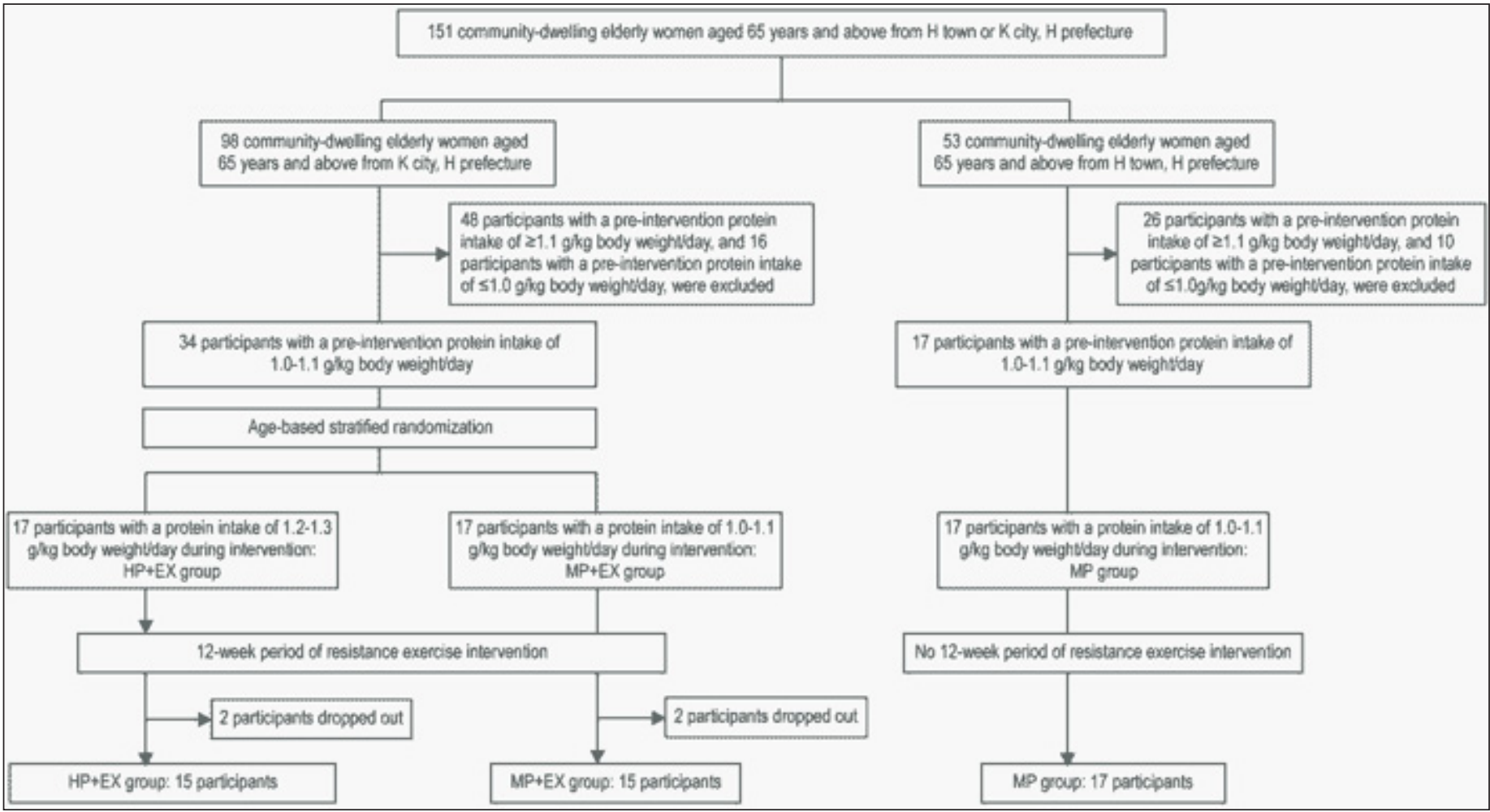

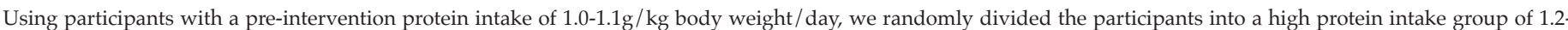

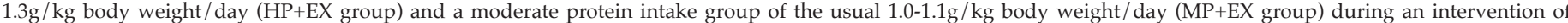
light-to-moderate intensity resistance exercise. We also established a moderate protein intake group of the usual $1.0-1.1 \mathrm{~g} / \mathrm{kg}$ body weight.

performing moderate intensity resistance exercises that used their own body weight and resistance bands, thereby preventing sarcopenia.

\section{Methods}

\section{Participants}

Participants were 151 Japanese women, $\geq 65$ years old, living in Hyogo Prefecture, in either City K or Town $\mathrm{H}$.

With the aim of using the DRI level of protein intake (1.0-1.1 g/ kg/day12) as a baseline reference, a dietary survey was used to screen the daily protein intake of prospective participants. Based on this dietary survey, 26 participants were excluded as their total daily protein intake was $<1.0 \mathrm{~g} / \mathrm{kg} /$ day, and 74 participants for a daily protein intake $>1.1 \mathrm{~g} / \mathrm{kg} /$ day. Remaining participants were randomly allocated to three groups of 17 participants: an exercise intervention group with protein intake adjusted to the DRI of $1.0-1.1 \mathrm{~g} / \mathrm{kg} /$ day $(\mathrm{MP}+\mathrm{EX}$ group); an exercise intervention group with protein intake adjusted above the DRI at $1.2-1.3 \mathrm{~g} / \mathrm{kg} / \mathrm{day}$ (HP+EX group); and a control group who participated in classroom-based session on nutrition management, with their protein intake adjusted to the DRI of 1.0-1.1 g/ $\mathrm{kg}$ / day (MP group). A stratified randomization strategy was used to achieve a comparable age distribution across groups. Over the study period, 4 participants withdrew due to family circumstances or poor physical conditioning, 2 participants from the HP+EX group and 2 participants from the $\mathrm{MP}+\mathrm{EX}$ group. The information from these 4 participants was excluded from analysis, with the final study group formed of 15 participants in the $\mathrm{HP}+\mathrm{EX}$ group, 15 participants in the $\mathrm{MP}+\mathrm{EX}$ group, and 17 participants in the MP group (Figure 1).

\section{Intervention design}

A 12-week program was implemented. Groups $\mathrm{HP}+\mathrm{EX}$ and $\mathrm{MP}+\mathrm{EX}$ completed a standardized program of resistance exercise and a nutrition management, with MP group completed a classroom-based program on nutrition.

\section{Measurement of body weight and physical composition}

Body weight and physical composition were measured by multi-frequency bioelectrical impedance analysis (In Body 430, Bio Space, Seoul, Korea). The following parameters of body composition were obtained: body mass index (BMI), body fat percentage, lean body mass (LBM), and total limb muscle mass, which was calculated separately for the upper and lower limbs, and for the 
trunk.

\section{Measurement of physical functions}

The following measures of physical function were evaluated: grip strength, knee extension strength, 5-m maximum walking speed, and timed up-and-go (TUG). Grip and knee extension strength were measured by hand held dynamometry (T.K.K5401; Takei Instruments, Tokyo, Japan. $\mu$-tus F-100; ANIMA., Tokyo, Japan). Measures were taken twice, and the maximum value recorded for analysis.

\section{Nutritional survey}

A nutritional survey was conducted to document: total energy intake (TEI), total and adjusted protein intake ( $\mathrm{g} / \mathrm{kg} /$ day), total fat intake, and total carbohydrate intake. The survey was complemented by food weighing methods (Excel Eiyou version 5.0; Kenpakusha, Tokyo, Japan). The nutrition questionnaire and weighing were completed for 5 consecutive days before the start of the program, and daily during the 12 -week intervention.

\section{Daily activity survey}

Participants recorded their daily activity for three consecutive days before the start of the program, with the information used to calculate each participant's regular physical activity level (PAL). Again, individual interviews were used to complete missing information. The estimated energy requirement (EER) to meet each individual's PAL was calculated as follows: EER = basal metabolic rate $\times$ body weight $(\mathrm{kg}) \times$ PAL (12) .

\section{Exercise intervention}

The exercise intervention consisted of a series of body weight resisted and resistance band exercises, performed 3 times per week for 12 weeks. Twice per week, exercises were performed under supervision of an exercise specialist, with participants completing the third session at home.

\section{Resistance exercises}

Body weight resisted exercises consisted of the following: abdominal crunches, rising and sitting from a chair; leg extensions; standing heel kicks, and calf raises. Five exercises were also performed with elastic bands (REP BAND; Magister Corporation, Chattanooga, TN): arm curls, pull-ups, leg extensions, squats, and sit-ups. Elastic bands of five difference resistance were used, with the level of resistance individually adjusted using 1 maximum repetition (1RM) testing for the upper and lower limbs prior to the intervention. The resistance load was modified in standardized fashion over the 12-week program as follows: for weeks 1-4, participants performed 2 sets of 10 repetitions each of the body weight resisted exercises and 2 sets of 20 repetitions of the resistance band exercises, at a resistance load of 50\% 1RM; for weeks 5-8, participants performed 2 sets of 15 repetitions each of the body weight resisted exercises and 2 sets of 15 repetitions each of the resistance band exercises at $60 \%$ 1RM; and for weeks 9-12, participants performed 3 sets of 15 repetitions each of the body weight resisted exercises and 3 sets of 12 repetitions each of the resistance band exercises at $70 \%$ 1RM.

\section{Nutritional intervention}

Total protein intake in the $\mathrm{HP}+\mathrm{EX}$ group was adjusted to a daily level of $1.2-1.3 \mathrm{~g} / \mathrm{kg} /$ day. Participants' were advised to increase their protein intake in their standard meals (breakfast, lunch, and dinner). The total protein intake for participants in the MP+EX and MP groups was adjusted to $1.0-1.1 \mathrm{~g} / \mathrm{kg} /$ day.

\section{Nutritional management}

Nutritional management was provided by a nutritionist, based on the DRIs (14) and results of the nutrition survey conducted before the intervention. Nutritional management was provided according to the following schedule: once to all participants prior to the onset of the study; as part of the group nutrition guidance sessions in intervention weeks 1-2; and on an individual basis, twice per week, for intervention weeks 3-12. At these individual sessions, protein intake was verified to ensure compliance with group-specific levels. Daily activity surveys were also reviewed to ensure sufficient TEI for all participants.

\section{Statistical analysis}

Individual changes in EER and TEI, pre- and postintervention, were evaluated using paired t-test analysis. Between-group differences in outcome variables, measured pre- and post-intervention, were evaluated using two-way analysis of variance (ANOVA). Changes in measured outcomes of muscle mass, physical function, and nutrient intake were evaluated between groups $(\mathrm{HP}+\mathrm{EX}, \mathrm{MP}+\mathrm{EX}$ and $\mathrm{MP})$ and time (pre- and postintervention) using a repeated measures ANOVA with group as an independent factor and time as the repeated factor. For identified main effects and interactions, multiple comparisons were performed using the Tukey post hoc analysis, with specific change in pre- and postintervention values compared using an unpaired one-way ANOVA. All statistical analyzes were performed using IBM SPSS statistical software (IBM, Tokyo, Japan), with the level of significance defined as a $\mathrm{p}$ value $<0.05$. 


\section{Results}

Baseline measures of body composition and physical function are listed in Table 1. Pre-intervention, measures were comparable between groups. Adherence to the schedule of resistance exercise of three sessions per week for 12 weeks was comparable for the two exercise groups, with a mean (SD) number of sessions completed of $34.3 \pm 1.2$, out of a possible maximum of 36 , for the HP+EX group (95.3\%) and $34.0 \pm 1.0$ for the MP+EX group (94.4\%).

Table 1

Physical characteristics of subjects pre-intervention

\begin{tabular}{lccc}
\hline & $\begin{array}{c}\text { HP+EX group } \\
(\mathbf{n}=\mathbf{1 5})\end{array}$ & $\begin{array}{c}\text { MP+EX group } \\
(\mathbf{n}=\mathbf{1 5})\end{array}$ & $\begin{array}{c}\text { MP group } \\
(\mathbf{n}=\mathbf{1 7})\end{array}$ \\
\hline Age & $69.8 \pm 2.1$ & $69.9 \pm 1.8$ & $69.4 \pm 2.9$ \\
Height $(\mathrm{cm})$ & $152.6 \pm 3.9$ & $151.3 \pm 4.3$ & $151.9 \pm 3.3$ \\
Weight $(\mathrm{kg})$ & $48.2 \pm 3.8$ & $48.2 \pm 3.6$ & $48.1 \pm 4.0$ \\
BMI $2\left(\mathrm{~kg} / \mathrm{m}^{2}\right)$ & $20.7 \pm 1.5$ & $21.1 \pm 1.4$ & $20.9 \pm 2.0$ \\
Body fat $(\%)$ & $24.9 \pm 2.9$ & $24.4 \pm 3.1$ & $23.8 \pm 2.8$ \\
LBM $(\mathrm{kg})$ & $36.1 \pm 2.4$ & $36.4 \pm 2.5$ & $36.6 \pm 3.1$ \\
Physical activity level & $1.75 \pm 0.06$ & $1.75 \pm 0.07$ & $1.75 \pm 0.07$ \\
Estimated energy requirement & $1,745 \pm 142$ & $1,748 \pm 111$ & $1,741 \pm 106$ \\
\hline
\end{tabular}

Mean value \pm Standard deviation; The results of a non-paired one-way ANOVA showed no differences in the characteristics of the 3 groups preintervention; HP+EX group: Protein intake of $1.2-1.3 \mathrm{~g} / \mathrm{kg}$ body weight/day during the 12-week period of exercise intervention; MP+EX group: Protein intake of 1.0-1.1 g/ $\mathrm{kg}$ body weight/day during the 12-week period of exercise intervention; MP group: Protein intake of 1.0-1.1 g/ $\mathrm{kg}$ body weight/day for the 12-week period; BMI: Body mass index; LBM: Lean body mass

Changes in measures of muscle mass pre- and postintervention are reported in Table 2. A significant main effect of exercise on limb muscle mass was identified $(p<0.05)$ with the largest change identified for the HP+EX group ( $\mathrm{p}<0.001$ compared to both the MP+EX and MP groups). A significant group $X$ limb interaction was identified $(\mathrm{p}<0.05)$, with a significantly higher increase in muscle mass for the HP+EX group, compared to the MP group, for the upper limbs $(\mathrm{p}<0.05)$, trunk $(\mathrm{p}<0.001)$ and lower limbs $(p<0.001)$. Comparing HP+EX and MP+EX groups, the magnitude of change in muscle mass was higher for the HP+EX group only for the lower limbs $(\mathrm{p}<0.05)$.

Effects of the intervention physical function are reported in Table 2. The ANOVA identified significant effects of exercise on knee extensor strength and 5-m maximum walking speed, as well as knee extensor strength $x$ TUG interaction. Change in knee extensor strength was higher for the MP+EX group, compared to the MP group $(p<0.01)$, with the highest magnitude of change obtained by the HP+EX group $(\mathrm{p}<0.001$ compared to MP; $\mathrm{p}<0.05$ compared to MP+EX group). Findings were similar for 5-m maximum walking speed, with greater improvement in walking speed in the MP+EX compared to MP groups $(\mathrm{p}<0.05)$, and largest increase for the HP+EX group ( $\mathrm{p}<0.001$ compared to MP; $\mathrm{p}<0.01$ compared to $\mathrm{MP}+\mathrm{EX}$ group). The improvement in TUG was greater for the HP+EX compared to the MP group $(\mathrm{p}<0.01)$.

Nutritional intake, TEI, EER, and levels of total protein intake, adjusted protein intake $/ \mathrm{kg}$ body weight, fat, and carbohydrates are listed in Table 3. Significant changes in TEI and protein intake (TEI, $\mathrm{p}<0.05$; protein, $\mathrm{p}<0.001$ ), as well as an interaction between adjusted protein intake and body weight $(\mathrm{p}<0.001)$ were identified. The magnitude of change was higher for the HP+EX group compared to the MP group (TEI, $\mathrm{p}<0.05$; protein intake / $\mathrm{kg}, \mathrm{p}<0.001$ ) and the MP+EX group (TEI, $\mathrm{p}<0.05$; protein intake $/ \mathrm{kg}, \mathrm{p}<0.001$ ).

\section{Discussion}

In this study, we evaluated the effectiveness of providing an adjusted protein intake of $1.2-1.3 \mathrm{~g} / \mathrm{kg} /$ day during a 12-week program of light-to-moderate intensity weight-bearing and resistance band exercises on the skeletal muscle mass and physical function of elderly women. The adjusted protein intake improved selected parameters of body composition and physical function, namely lower limb muscle mass, knee extension strength, and 5-m maximum walking speed. The mean protein intake for the HP+EX group was $11.4 \pm 1.8 \mathrm{~g} /$ day, and increased by approximately $0.22 \pm 0.02 \mathrm{~g} / \mathrm{kg} /$ day over the 12-week program. Fat and carbohydrate intake were comparable between groups and TEI was never below EER.

Our current results support our a priori hypothesis of the necessity of increasing protein intake to optimize outcomes of exercise on muscle mass and physical function in the elderly. In fact, total limb muscle mass increased by $0.9 \pm 0.3 \mathrm{~kg}$ when combining increased protein intake and exercise (HP+EX), compared to $0.2 \pm 0.4$ $\mathrm{kg}$ for exercise alone (MP+EX). Our measured effect of exercise alone is comparable to results reported by Kim et al. (15) of a $0.29 \mathrm{~kg}$ increase in total limb mass for elderly Japanese women completing a 12-week program. Kim et al. (15) combined resistance exercises with amino acid supplements, reporting an increase of approximately $0.34 \mathrm{~kg}$ in total limb muscle mass. Using an adjusted protein intake, our program surpassed these levels with a mean increase in total limb mass of $0.9 \mathrm{~kg}$, with the most significant increase noted for the lower limbs. This lower limb bias may be explained by performance of a higher number of lower limb exercises. An important difference in our study, compared to Kim et al. (15), is that we graduated the workload of our program over the 12-weeks.

An important outcome of our study was the identification of a $0.2 \pm 0.7 \mathrm{~kg}$ decrease in total limb muscle mass and $0.2 \pm 1.0 \mathrm{~kg}$ decrease in knee extension strength for participants in the MP group over the study period. This emphasizes the need to adjust protein intake, at least 
Table 2

Comparison of limb muscle mass and physical functions pre-/post-intervention

\begin{tabular}{|c|c|c|c|c|c|c|c|c|c|c|c|}
\hline & \multicolumn{3}{|c|}{ Pre-intervention } & \multicolumn{3}{|c|}{ Post-intervention } & \multirow{2}{*}{$\begin{array}{c}\text { Main } \\
\text { effect of } \\
\text { time }\end{array}$} & \multirow{2}{*}{$\begin{array}{c}\begin{array}{c}\text { Group } \\
\text { xtime } \\
\text { interaction }\end{array} \\
\end{array}$} & \multicolumn{3}{|c|}{$\begin{array}{l}\Delta \text { (Post-intervention - } \\
\text { Pre-intervention) }\end{array}$} \\
\hline & $\begin{array}{c}\text { MP } \\
\text { group }\end{array}$ & $\begin{array}{l}\text { MP+EX } \\
\text { group }\end{array}$ & $\begin{array}{l}\mathrm{HP}+\mathrm{EX} \\
\text { group }\end{array}$ & $\begin{array}{c}\text { MP } \\
\text { group }\end{array}$ & $\begin{array}{c}\mathrm{MP}+\mathrm{EX} \\
\text { group }\end{array}$ & $\begin{array}{l}\mathrm{HP}+\mathrm{EX} \\
\text { group }\end{array}$ & & & $\begin{array}{c}\text { MP } \\
\text { group }\end{array}$ & $\begin{array}{c}\mathrm{MP}+\mathrm{EX} \\
\text { group }\end{array}$ & $\begin{array}{l}\mathrm{HP}+\mathrm{EX} \\
\text { group }\end{array}$ \\
\hline Total limb muscle mass (kg) & $29.3 \pm 2.5$ & $29.1 \pm 2.0$ & $28.9 \pm 1.9$ & $29.1 \pm 2.6$ & $29.3 \pm 2.2$ & $29.8 \pm 2.0$ & *** & *** & $-0.2 \pm 0.7$ & $0.2 \pm 0.4+$ & $0.9 \pm 0.3+十+$ ，㧊 \\
\hline Upper limb muscle mass (kg) & $2.0 \pm 0.1$ & $2.0 \pm 0.1$ & $2.0 \pm 0.1$ & $2.1 \pm 0.2$ & $2.1 \pm 0.2$ & $2.1 \pm 0.2$ & $* * *$ & * & $0.0 \pm 0.1$ & $0.1 \pm 0.0$ & $0.1 \pm 0.2+$ \\
\hline Trunk muscle mass (kg) & $14.7 \pm 1.2$ & $14.6 \pm 1.0$ & $14.5 \pm 1.0$ & $14.5 \pm 1.3$ & $14.6 \pm 1.1$ & $14.7 \pm 1.0$ & & * & $-0.1 \pm 0.4$ & $0.0 \pm 0.2$ & $0.2 \pm 0.2+\dagger$ \\
\hline Lower limb muscle mass (kg) & $12.6 \pm 1.1$ & $12.5 \pm 0.9$ & $12.4 \pm 0.8$ & $12.5 \pm 1.1$ & $12.6 \pm 0.9$ & $12.8 \pm 1.0$ & ** & *** & $-0.1 \pm 0.3$ & $0.1 \pm 0.2$ & $0.4 \pm 0.3++十, \neq$ \\
\hline Grip strength $(\mathrm{kg})$ & $21.2 \pm 2.2$ & $20.6 \pm 1.8$ & $19.7 \pm 2.6$ & $21.1 \pm 1.7$ & $21.0 \pm 1.7$ & $20.4 \pm 2.9$ & * & & $0.0 \pm 1.2$ & $0.3 \pm 0.5$ & $0.7 \pm 0.6$ \\
\hline Knee extension strength $(\mathrm{kg})$ & $19.7 \pm 2.1$ & $20.2 \pm 1.7$ & $19.5 \pm 2.4$ & $19.5 \pm 2.1$ & $20.9 \pm 2.0$ & $20.9 \pm 2.6$ & $* * *$ & $* * *$ & $-0.2 \pm 1.0$ & $0.7 \pm 0.6++$ & $1.4 \pm 0.4+† \dagger, \ddagger$ \\
\hline $\begin{array}{l}\text { 5-m maximum walking speed } \\
(\mathrm{m} / \mathrm{s})\end{array}$ & $1.80 \pm 0.17$ & $1.80 \pm 0.12$ & $1.82 \pm 0.20$ & $1.81 \pm 0.17$ & $1.84 \pm 0.12$ & $1.92 \pm 0.19$ & $* * *$ & $* * *$ & $0.01 \pm 0.05$ & $0.04 \pm 0.04 \dagger$ & $0.09 \pm 0.04++十$,キキ \\
\hline Timed up \& go $(\mathrm{m} / \mathrm{s})$ & $0.91 \pm 0.05$ & $0.89 \pm 0.07$ & $0.91 \pm 0.07$ & $0.91 \pm 0.06$ & $0.90 \pm 0.07$ & $0.93 \pm 0.07$ & $* * *$ & ** & $0.00 \pm 0.02$ & $0.01 \pm 0.01$ & $0.02 \pm 0.01++$ \\
\hline
\end{tabular}

to the minimum DRI of $1.0-1.1 \mathrm{~g} / \mathrm{kg} /$ day, in combination with a light-to-moderate program of resistance training, to maintain muscle mass, with further adjustment in protein intake yielding more significant results.

According to Chevalier et al. (16), a dietary protein intake of $0.8 \mathrm{~g} / \mathrm{kg} /$ day is insufficient for increasing the skeletal muscle mass of elderly persons and intake should be increased to levels of at least $1.2 \mathrm{~g} / \mathrm{kg} /$ day. Several physiological reasons contribute to the increased requirement of protein intake in the elderly. Drummond et al. (17) reported a delay and/or decrease of the signaling responses to amino acids in skeletal muscle cells with age. Volpi et al. (18) further demonstrated that a higher proportion of the amino acids absorbed in the gastrointestinal tract of elderly persons is metabolized in the small intestine and liver. Although specific physiological measurements related to protein metabolism were not included in our study, our outcomes provide evidence of insufficient muscle protein synthesis during resistance exercise with a moderate adjustment of protein intake to levels of $1.0-1.2 \mathrm{~g} / \mathrm{kg} /$ day and that a higher adjustment to levels of $1.2-1.3 \mathrm{~g} / \mathrm{kg} /$ day are required to enhance effectiveness of resistance training on muscle mass and strength.

Our light-to-moderate level of resistance was sufficient to maintain muscle mass and strength in the MP+EX group. Levinger et al. (19) reported a 1.1-kg increase in skeletal muscle mass of elderly participants performing a 10-week program of high-intensity resistance exercises. In their review of research evidence for resistance training in elderly individuals, Miyachi et al. (20) indicated that an exercise intensity of $80 \% 1 \mathrm{RM}$ or above is required to increase the skeletal muscle mass with a single intervention of exercise. It is important to note that the participants in our study group had a relatively low PAL of 1.75; as none of our participants engaged in regular resistance training, prescription of a high-intensity program was not possible. Future research is required to more clearly elucidate the effectiveness of supplemented protein intake and different levels of resistance training for enhancing gains in muscle mass and strength. However, we do emphasize that our program of light-tomoderate resistance was effective, with a practice rate of approximately $95 \%$, and can be safely implemented as a home program for elderly individuals who are relatively deconditioned.

The benefits of combining a light-to-moderate resistance training program with nutritional supplementation in lowering the risk for sarcopenia in elderly individuals is supported by previous research. In their review comparing the transient response of muscles to high- and low-intensity resistance training regimes, Mallinson et al. (21) reported an increase in muscle protein synthesis (and increased muscle protein reserves) with high-intensity resistance exercise, performed at $90 \%$ $1 \mathrm{RM}$, while low-intensity resistance exercises, performed at $30 \%$ 1RM, stimulated muscle protein synthesis. Therefore, light-to-moderate intensity weight-bearing and resistance band resistance exercise can have benefits for elderly women, who can easily perform these exercises.

In our study, we assumed that a training resistance of $50-70 \%$ 1RM would have little stimulus on protein synthesis in skeletal muscle. As a result, we did not include a control group of adjusted high protein intake alone, with no participation in the program of exercise. Therefore, we are unable to determine if the increase in muscle mass for the HP+EX group results from the increase in protein intake or from the combination of increased protein intake and exercise. Future research is required to clarify the pathway of muscle mass increase associated to a combination of supplemented protein intake and exercise. Another important limitation of our study is the inclusion only of women to control for known sex-specific differences in age-related muscle atrophy and sarcopenia $(22,23)$. Future research will need to verify effectiveness of protein supplementation in elderly 
Table 3

Comparison pre-intervention and during intervention

\begin{tabular}{|c|c|c|c|c|c|c|c|c|c|c|c|}
\hline & \multicolumn{3}{|c|}{ Pre-intervention } & \multicolumn{3}{|c|}{ During intervention } & \multirow{2}{*}{$\begin{array}{l}\text { Main } \\
\text { effect of } \\
\text { time }\end{array}$} & \multirow{2}{*}{$\begin{array}{c}\text { Group } \\
\times \text { time } \\
\text { intervention }\end{array}$} & \multicolumn{3}{|c|}{$\Delta$ (Post-intervention - Pre-intervention) } \\
\hline & $\begin{array}{l}\text { MP } \\
\text { group }\end{array}$ & $\begin{array}{l}\text { MP+EX } \\
\text { group }\end{array}$ & $\begin{array}{l}\text { HP+EX } \\
\text { group }\end{array}$ & $\begin{array}{l}\text { MP } \\
\text { group }\end{array}$ & $\begin{array}{l}\text { MP+EX } \\
\text { group }\end{array}$ & $\begin{array}{l}\text { HP+EX } \\
\text { group }\end{array}$ & & & $\begin{array}{c}\text { MP } \\
\text { group }\end{array}$ & $\begin{array}{l}\text { MP+EX } \\
\text { group }\end{array}$ & $\begin{array}{l}\text { HP+EX } \\
\text { group }\end{array}$ \\
\hline $\begin{array}{l}\text { Total energy intake } \\
\text { (kcal/day) }\end{array}$ & $1,832 \pm 107$ & $1,833 \pm 144$ & $1,847 \pm 143$ & $1,843 \pm 79$ & $1,851 \pm 168$ & $1,933 \pm 140$ & ** & * & $10 \pm 80$ & $18 \pm 123$ & $87 \pm 89+$ † \\
\hline Protein (g/day) & $49.2 \pm 3.7$ & $49.0 \pm 3.2$ & $49.2 \pm 3.5$ & $49.3 \pm 4.0$ & $49.7 \pm 2.9$ & $60.6 \pm 4.8$ & *** & $* * *$ & $0.1 \pm 0.7$ & $0.7 \pm 1.1$ & $11.4 \pm 1.8+十+$ ，㧊 \\
\hline $\begin{array}{l}\text { Protein/body weight } \\
\text { (g/kg/day) }\end{array}$ & $1.02 \pm 0.02$ & $1.01 \pm 0.01$ & $1.02 \pm 0.01$ & $1.03 \pm 0.02$ & $1.02 \pm 0.02$ & $1.24 \pm 0.02$ & $* * *$ & $* * *$ & $0.01 \pm 0.01$ & $0.00 \pm 0.02$ & 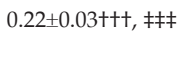 \\
\hline Fat (g/day) & $53.5 \pm 9.0$ & $52.7 \pm 5.4$ & $52.7 \pm 10.2$ & $54.5 \pm 8.9$ & $53.6 \pm 5.5$ & $56.7 \pm 5.3$ & & & $1.0 \pm 11.1$ & $0.9 \pm 4.5$ & $4.0 \pm 11.5$ \\
\hline $\begin{array}{l}\text { Carbohydrates (g/ } \\
\text { day) }\end{array}$ & $288.6 \pm 18.2$ & $290.7 \pm 33.4$ & $293.9 \pm 31.8$ & $288.8 \pm 22.7$ & $292.5 \pm 31.6$ & $295.2 \pm 26.2$ & & & $0.2 \pm 23.4$ & $1.8 \pm 31.5$ & $1.3 \pm 30.5$ \\
\hline
\end{tabular}

Mean value \pm Standard deviation, Two-way ANOVA by time (Pre- and post-intervation period) $\times$ group $\left(\mathrm{HP}+\mathrm{EX}, \mathrm{MP}+\mathrm{EX}, \mathrm{MP}\right.$ group), ${ }^{*} \mathrm{p}<0.05,{ }^{* *} \mathrm{p}<0.01,{ }^{* * *} \mathrm{p}<0.001$; One-way ANOVA and post-hoc by Tukey test, significant difference with MP group: $t \mathrm{p}<0.05,+++\mathrm{p}<0.001$, Significant difference with $\mathrm{MP}+\mathrm{EX}$ group: $\neq \mathrm{p}<0.05, \neq \neq \neq \mathrm{p}<0.001$

men. Moreover, we estimated muscle mass from BIA measurements. There are currently no population norms of BIA measurements for elderly women, and research is needed to establish norms compared to DEXA (24). Finally, the present study is that the sample size was too small, and the conclusion was not well supported by this data. For example, SD of total limb muscle mass is 1.9 and the change by intervention was $0.9 \mathrm{~kg}$ in $\mathrm{HP}+\mathrm{EX}$ group. Required sample size to make this change as significant is 37, which is more than twice of the actual number of sample.

Our study provides evidence of the benefit of increasing protein intake as one component of a resistance training program to improve muscle mass and strength in elderly women.

Funding: This work was supported by JSPS KAKENHI Grant Number 25750353. The sponsors had no role in the design and conduct of the study; in the collection, analysis, and interpretation of data; in the preparation of the manuscript; or in the review or approval of the manuscript.

Acknowledgements: None.

Conflict of Interest: All of the authors declare that they have no conflicts of interest regarding this paper.

Ethical standards: Ethics Committee of Hyogo University (approved \# 12003).

\section{References}

1. Evans WJ. What is sarcopenia? J Gerontol A Biol Sci Med Sci 1989;50A:5-8.

2. Janssen I, Baumgartner RN, Ross R. Skeletal muscle cutpoints associated with elevated physical disability risk in older men and women. Am J Epidemiol 2004;159:413 - 421.

3. Roubenoff R, Hughes VA. Sarcopenia: current concepts. J Gerontol A Biol Sci Med Sci 2000;55:716-724.

4. Robinson S, Cooper C, Aihie SA. Nutrition and sarcopenia: a review of the evidence and implications for preventive strategies. J Aging Res 2012;2012. (ID 510801). http:// dx.doi.org/10.1155/2012/510801

5. Christie J. Progressive resistance strength training for improving physical function in older adults. Int J Older People Nurs 2011;6:244 - 246.

6. Peterson MD, Rhea MR, Sen A. Resistance exercise for muscular strength in older adults: a meta-analysis. Ageing Res Rev 2010;9:226-237.

7. Taaffe DR. Sarcopenia: exercise as a treatment strategy. Aust Fam Physician 2006;35:130-134.
8. Doherty TJ. Invited review: aging and sarcopenia. J Appl Physiol 2003;95:1717-1727.

9. Beasley JM, Shikany JM, Thomson CA. The role of dietary protein intake in the prevention of sarcopenia of aging. Nutr Clin Pract 2013;28:684-690.

10. Morley JE, Argiles JM, Evans WJ, et al. Society for Sarcopenia, Cachexia, and Wasting Disease. Nutritional recommendations for the management of sarcopenia. J Am Med Dir Assoc 2010;11:391-396.

11. Volkert D, Sieber CC. Protein requirements in the elderly. Int J Vitam Nutr Res 2011;81:109-119.

12. Nakade M, Imai E, Tsubota-Utsugi M. Systematic classification of evidence for dietary reference intakes for Japanese 2010 (DRIs-J 2010) in adults and future prospects of DRIs in Asian countries. Asia Pac J Clin Nutr 2013;22:474489.

13. Eckard T, Lopez J, Kaus A, Aden J. Home exercise program compliance of service members in the deployed environment: an observational cohort study. Mil Med 2015;180:186-191.

14. Mori H, Niwa M. Effect of nutritional care and whey protein supplementation on the body composition and physical function in older adults after combined resistance and aerobic exercise. Jpn J Nutr Diet 2014;72:12-20. [in Japanese]

15. Kim HK, Suzuki T, Saito K, et al. Effects of exercise and amino acid supplementation on body composition and physical function in communitydwelling elderly Japanese sarcopenic women: a randomized controlled trial. J Am Geriatr Soc 2012;60:16-23.

16. Chevalier S, Gougeon R, Nayar K, Morais JA. Frailty amplifies the effects of aging on protein metabolism: role of protein intake. Am J Clin Nutr 2003;78:422-429.

17. Drummond MJ, Dreyer HC, Pennings B, et al. Skeletal muscle protein anabolic response to resistance exercise and essential amino acids is delayed with aging. J Appl Physiol 2008;104:1452-1461.

18. Volpi E, Mittendorfer B, Wolf SE, Wolfe RR. Oral amino acids stimulate muscle protein anabolism in the elderly despite higher first-pass splanchnic extraction. Am J Physiol 1999;277:513-520.

19. Levinger I, Goodman C, Hare DL, Jerums G, Seling S. The effect of resistance training on functional capacity and quality of life in individuals with high and low numbers of metabolic risk factors. Diabetes Care 2007;30:2205-2210.

20. Miyachi M, Ando D, Oida $\mathrm{Y}$, et al. Possible treatments for sarcopenia: systematic review on the effect of exercise intervention. Jpn J Geriatr 2011;48:51-54. [in Japanese]

21. Mallinson JE, Murton AJ. Mechanisms responsible for disuse muscle atrophy: potential role of protein provision and exercise as countermeasures. Nutrition 2012;29:22-28.

22. Sanada K, Miyachi M, Tanimoto M, et al. A cross-sectional study of sarcopenia in Japanese men and women: reference values and association with cardiovascular risk factors. Eur J Appl Physiol 2010;10:57-65.

23. Basaria S, Coviello AD, Travison TG. Adverse events associated with testosterone administration. N Engl J Med 2010;8:109-122.

24. Buckinx F, Reginster JY, Dardenne N, et al. Concordance between muscle mass assessed by bioelectrical impedance analysis and by dual energy X-ray absorptiometry: a cross-sectional study. BMC Musculoskelet Disord 2015;16:60. 